\title{
A CONSTRUÇÃO DOS MÓDULOS DE UMA SEQUÊNCIA DIDÁTICA A PARTIR DA TRADUÇÃO FUNCIONALISTA PARA O ENSINO DA VARIAÇÃO LINGUÍSTICA
}

\author{
THE CONSTRUCTION OF THE MODULES OF A DIDACTIC SEQUENCE FROM \\ THE FUNCTIONALIST TRANSLATION FOR THE TEACHING OF LINGUISTIC \\ VARIATION
}

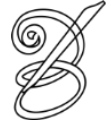 \\ Valdecy de Oliveira PONTES \\ Universidade Federal do Ceará ${ }^{1}$ \\ Livya Lea de Oliveira PEREIRA ${ }^{2}$ \\ Universidade Federal de Santa Catarina
}

Resumo: Através dos gêneros textuais nos expressamos e interagimos socialmente, por isso, estes têm papel central tanto para a Teoria da Tradução Funcionalista (REISS, VERMEER, 1996; NORD, 1994, 1996, 2012) quanto para o procedimento de Sequências Didáticas para o Ensino de Línguas (DOLZ, NOVERRAZ, SCHENEUWLY, 2004; CRISTÓVÃO, 2009, 2010; COSTA-HÜRBES, SIMIONI, 2014) e os Estudos Sociolinguísticos (LABOV, 1978). Assim, neste artigo, partimos dessas diferentes perspectivas teóricas, buscando interligá-las e ilustrar a construção dos módulos de uma Sequência Didática, nos moldes da Escola de Genebra, a partir da Tradução Funcionalista de peças teatrais hispânicas para o ensino da variação linguística nos usos das formas de tratamento do Português Brasileiro e do Espanhol.

Palavras-chave: Tradução Funcionalista. Sequências Didáticas. Variação Linguística. Formas de tratamento.

Abstract: Through textual genres we express and interact socially, therefore, they play a central role both in the Functionalist Translation Theory (Reiss, Vermeer, 1996; NORD, 1994, 1996, 2012) and in the procedure of Didactic Sequences for Language Teaching (DOLZ, NOVERRAZ, SCHENEUWLY, 2004; CRISTÓVÃO, 2009, 2010; COSTA-HÜRBES, SIMIONI, 2014) and Sociolinguistic Studies (LABOV, 1978).Thus, in this article, we start from these different theoretical perspectives, looking for interconnecting them and illustrating the construction of the modules of a Didactic Sequence, in the molds of the Geneva School, from the Functionalist Translation of Hispanic plays for the teaching of linguistic variation in the uses of the treatment forms of Brazilian Portuguese and Spanish.

Keywords: Functionalist Translation. Didactic Sequences. Linguistic Variation. Treatment Form.

RECEBIDO EM: 19/03/2017

ACEITO EM: 26/06/2017

PUBLICADO EM: julho 2018

PONTES; PEREIRA. A construção dos módulos de uma sequência didática a partir da tradução funcionalista para o ensino da variação linguística Belas Infiéis, v. 7, n. 1, p. 175-200, 2018. 


\section{Contextualizando}

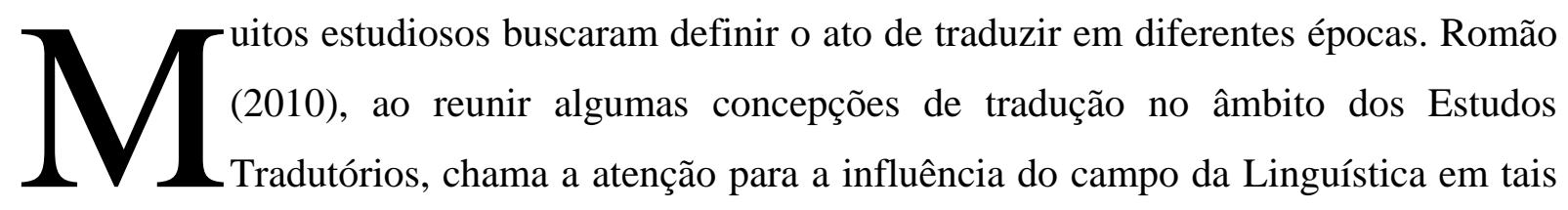
definições. Ademais, esse autor nota a predominância de uma visão formalista do ato tradutório, no qual a tradução era entendida, muitas vezes, como equivalência linguística, no âmbito frasal e lexical, e, ainda, manutenção do significado (sentido) do texto de partida. Esta visão permeava, também, o uso da tradução no contexto de ensino de Língua Estrangeira (LE) com a abordagem Gramática e Tradução e Abordagem da Leitura.

No entanto, na década de 1970, em oposição às abordagens linguísticas formalistas, surge a perspectiva funcionalista, como escola linguística. Nesta, as funções da linguagem possuíam papel central e estavam diretamente relacionadas aos fatores que intervinham na comunicação e na intenção pragmática. Logo, entendia-se a linguagem como prática de interação social. Tal visão de língua, no âmbito do Ensino de LE, influenciou a Abordagem Nócio-funcional e, posteriormente, a Abordagem Comunicativa (AC). Por sua vez, no âmbito 176 dos Estudos da Tradução, esta visão também ganhou força e influenciou a vertente alemã conhecida como Teoria Funcional da Tradução ou Tradução Funcionalista (ZIPSER; POLCHLOPEK, 2011).

Em relação à escolha do objetivo de estudo, Masello (2011) afirma que o terreno das formas de tratamento pode consistir em um desafio a quem se propõe a traduzir, pois ao escolher a forma de tratamento em Espanhol (tú, vos, usted, vosotros ou ustedes), no uso e na distribuição do sistema pronominal, em cada variedade linguística, há a prevalência de algum parâmetro de: solidariedade, idade, poder, gênero, grau de intimidade ou distância com o interlocutor, entre outros. Esses, por sua vez, condicionam a compreensão do texto e a comunicação.

O conhecimento desse fenômeno de variação linguística é relevante, também, para o aprendizado de línguas estrangeiras, uma vez que a adequação do comportamento linguístico ao contexto situacional faz parte da sub-competência sociolinguística. Assim, torna-se pertinente a prática de atividades que proporcionem o seu desenvolvimento com vistas a alcançar a competência comunicativa ${ }^{3}$ dos aprendizes. Logo, buscamos aliar a perspectiva teórica da Tradução Funcionalista à visão de língua heterogênea ${ }^{4}$ e aplicá-la de acordo com o procedimento de Sequências Didáticas (SD), proposto pela Escola de Genebra, vislumbrando um recurso didático útil em sala de aula para o ensino da variação linguística ${ }^{5}$ no uso das formas 
de tratamento pronominais da Língua Espanhola (tú, vos, usted, vosotros e ustedes) e Portuguesa (tu, você, senhor(es), senhora(s), vós, vocês) para um grupo de futuros professores brasileiros de Língua Espanhola em nível inicial (A2) ${ }^{6}$.

Para tanto, organizamos este texto em cinco seções, a saber: a presente contextualização; 2. Princípios da Tradução Funcionalista e potencialidades para a abordagem de conhecimentos sociolinguísticos no Ensino de Línguas Estrangeiras; 3. O procedimento de Sequências Didáticas a partir da Tradução Funcionalista; 4. Construindo os módulos de uma SD com a Tradução Funcionalista do Gênero Comédia Teatral; 5. Considerações Finais.

\section{Princípios da Tradução Funcionalista e potencialidades para a abordagem de conhecimentos sociolinguísticos no Ensino de Línguas Estrangeiras}

Sobre as bases da Tradução Funcionalista, Reiss e Vermeer (1996, p. 104), afirmam que, para a sua construção epistemológica: "Servem de fundamento determinadas partes da Pragmática Linguística, além dos conhecimentos de Sociologia e da Antropologia cultural” (tradução nossa). Assim, nota-se que esta perspectiva de tradução busca desprender-se do puramente linguístico, para incluir aspectos contextuais, culturais e interacionais. Reiss e Vermeer (1996, p. 18) asseveram que: “É mais adequado falar de 'translação intercultural' do que de 'translação interlingual', já que este último conceito é muito limitado.”

Nesta perspectiva de tradução, o objetivo ou finalidade da translação determinará todo o processo tradutório. Desse modo, percebe-se que, nesta concepção, busca-se a translação do texto em sua situação comunicativa. Por isso, é constituída e determinada por aspectos culturais e contextuais de sua produção e recepção, e, ainda, é entendida como uma oferta de informação entre culturas. Segundo os autores, a oferta informativa do texto-meta (TM) é uma oferta de informação sobre o sentido, modo, circunstâncias ou forma de outra oferta informativa, a do texto-base (TB). Portanto, trata-se de uma reprodução não reversível de modo unívoco, posto que é uma realização, na qual o tradutor escolhe entre as muitas possibilidades.

Dessa maneira, os autores concebem a translação como uma forma especial de interação que parte de um texto produzido com anterioridade. Assim, ainda que outros fatores determinem a translação, tais como fatores históricos e culturais, intencionalidade, finalidade, receptores, etc., esta dependerá, também, do TB e de suas condições de produção, nas quais a sua análise corresponde a uma teoria geral de produção de texto. Na concepção dos autores, a translação requer uma dupla ação: analisar as condições de produção do TB ou texto de partida

PONTES; PEREIRA. A construção dos módulos de uma sequência didática a partir da tradução funcionalista para o ensino da variação linguística 
e as condições de produção do TM, isto é, o texto de chegada (REISS; VERMEER, 1996, p. 14). Sobre esta questão, Christiane Nord postula grande contribuição através de seu modelo de análise pré-tradutória, exposto a seguir:

Quadro 1 - Modelo de Análise pré-tradutória de Nord (2012)

\begin{tabular}{|c|c|c|c|}
\hline & Perfil do texto base & Transferência & $\begin{array}{l}\text { Perfil do texto } \\
\text { meta }\end{array}$ \\
\hline \multicolumn{4}{|c|}{ Aspectos extratextuais } \\
\hline \multicolumn{4}{|l|}{ Emissor } \\
\hline \multicolumn{4}{|l|}{ Intenção } \\
\hline \multicolumn{4}{|l|}{ Receptor } \\
\hline \multicolumn{4}{|l|}{ Meio } \\
\hline \multicolumn{4}{|l|}{ Lugar } \\
\hline \multicolumn{4}{|l|}{ Tempo } \\
\hline \multicolumn{4}{|l|}{ Motivo } \\
\hline \multicolumn{4}{|l|}{ Função } \\
\hline \multicolumn{4}{|c|}{ Aspectos intratextuais } \\
\hline \multicolumn{4}{|l|}{ Tema } \\
\hline \multicolumn{4}{|l|}{ Conteúdo } \\
\hline \multicolumn{4}{|l|}{ Pressuposições } \\
\hline \multicolumn{4}{|l|}{ Composição } \\
\hline \multicolumn{4}{|l|}{$\begin{array}{ll}\text { Elementos não } \\
\text { verbais }\end{array}$} \\
\hline \multicolumn{4}{|l|}{ Léxico } \\
\hline \multicolumn{4}{|l|}{ Sintaxe } \\
\hline \multicolumn{4}{|l|}{ Suprassegmentais } \\
\hline \multicolumn{4}{|c|}{ Efeito comunicativo } \\
\hline Efeito & & & \\
\hline
\end{tabular}

Fonte: NORD, 2012, p. 155; tradução nossa.

Nesta perspectiva, Nord (2012) expõe que a translação é a produção de um TM funcional, que mantenha uma interdependência com um TB, especificada segundo o seu propósito comunicativo. Para alcançar essa funcionalidade, é necessário analisar os aspectos intra e extratextuais do TB e compará-los com o contexto de produção do TM. Neste sentido, os fatores extratextuais podem ser analisados ao se buscar responder sobre quem transmite (autor/emissor) o texto, para que (intenção emissora), a quem (destinatário), por qual meio transmissor, onde, quando e o porquê (lugar, tempo e motivo da comunicação). Tais respostas proporcionarão, também, identificar a função textual. Busca-se, igualmente, analisar a temática, o conteúdo, as informações pressupostas como conhecidas pelo destinatário, a ordem de composição ou organização do texto, os elementos não verbais, o tipo de léxico utilizado, a sintaxe e a prosódia ou entonação. 
Assim, a análise global de tais elementos extra e intratextuais especificarão o efeito do texto. Logo, ao utilizar tal modelo no âmbito do ensino de línguas, o professor pode facilitar a análise e, por conseguinte, a tradução, ao disponibilizar o máximo de informação possível, inclusive com objetivos claros no que se refere ao encargo de tradução didática (que trataremos posteriormente). Nord (2012, p. 154) explicita exemplos de aplicação didática do seu modelo de análise pré-tradutória, no âmbito da Didática de Tradução. Porém, não descarta o seu uso no contexto de Ensino de LE, desde que não se limite à análise linguística do TB ou às intenções do autor e sua verbalização.

Ainda, no que tange à Didática da Tradução Funcional, Nord (1996) postula os seguintes princípios para a formulação de um encargo de tradução, isto é, uma situação comunicativa que exija o ato tradutório: 1. princípio da autenticidade, o qual consiste em escolher atividades de tradução de textos autênticos, reais e que tenham relevância para a prática profissional; 2 . princípio da comunicabilidade, o qual requer que os textos se apresentem em sua situação comunicativa ou em uma forma que se aproxime da situação que funciona ou que funcionou originalmente; 3. princípio da transparência, que significa que o professor deve deixar o mais claro possível para os aprendizes as suas expectativas sobre a qualidade do texto-meta, mediante um encargo de tradução detalhado.

Sobre estes, a autora destaca que, visando ao princípio da transparência, o encargo de tradução deve conter as seguintes informações sobre a situação-meta: 1. a função ou as funções comunicativas que o texto-meta deve alcançar; 2. os destinatários do texto-meta; 3. as condições temporais e locais previstos para a recepção do TM; 4. o meio pelo qual será transmitido o TM; e, 5. o motivo pelo qual se produz o texto. Tais informações, também, são necessárias ao elaborar uma atividade com o uso da tradução em aulas de LE, pois influenciarão a forma de tradução do texto. Por exemplo, ao propor a tradução de uma letra de música Espanhola ao Português, sem a intenção de ser uma versão cantada, para ser publicada em um site de letras traduzidas. Possivelmente, manter as rimas e aspectos poéticos da música não será o foco dos estudantes, tampouco corresponderá à função do TM perante o seu encargo de tradução.

Através de tal exemplo, podemos questionar se essa tradução seria equivalente ao seu TB. Pelo discorrido até então, nota-se que, nesta teoria, a equivalência entre o TM e o TB não visa apenas à correspondência forma/conteúdo, mas relaciona-se com a adequação do TM ao seu propósito específico, o encargo de tradução. Sobre o conceito de equivalência, Nord (1994, p. 100) postula seu próprio modelo, guiado tanto pela funcionalidade do TM para um 
determinado fim comunicativo quanto pela lealdade, no que diz respeito às intenções e expectativas do autor original do TB, do cliente ou iniciador e dos receptores do TM. Assim, para a autora, o tradutor, ao realizar sua tarefa de mediação entre as línguas e culturas, identifica os aspectos do TB que podem manter-se na tradução e os que serão adaptados, já que, nas palavras dela: "Todo processo translativo, portanto, consta de procedimentos conservadores e procedimentos de adaptação" (tradução nossa, NORD, 1994, p.100). A autora menciona, de modo semelhante, que a quantidade de elementos mantidos ou adaptados do TB dependerá do tipo de tradução escolhida e da distância cultural entre as línguas e culturas envolvidas.

É nessa adequação e lealdade do TM ao TB que os conhecimentos sociolinguísticos podem ter grande contribuição na prática tradutória, fato que possibilita, inclusive, a elaboração de propostas didáticas aplicadas com o uso da tradução para abordar o conhecimento sociolinguístico, como as de Barrientos (2014) e Pereira (2016). Por exemplo, se fossemos traduzir a seguinte pergunta "Você vai pro forró hoje com a Flávia?", realizada em uma conversa informal entre um cearense da cidade de Fortaleza e um colega chileno, por qual forma de tratamento pronominal chilena traduziríamos a forma "você"? Há diferentes formas de 180 tratamento pronominais para tratar a segunda pessoa do singular na variedade chilena, por exemplo, o voseo mixto (tú estái), o voseo completo (vos estái) e o ustedeo (usted está). Essas diversas formas para se referir ao mesmo significado referencial, num mesmo contexto e período diacrônico constituem um fenômeno de variação linguística (LABOV, 1978) que pode influenciar a compreensão do TM.

A variação linguística ocorre nos diferentes níveis linguísticos (fonético, léxico, sintático, morfológico, discursivo), sendo classificada como diatópica, diastrática, diafásica, diamésica e diacrônica. Sobre essa questão, Bolaños-Cuéllar (2000, p.158) defende no marco da interdisciplinaridade dos Estudos da Tradução que a Sociolinguística pode contribuir para a compreensão, análise e possíveis soluções de problemas de tradução, no tocante à preservação das formas de tratamento de uma língua a outra, conservação de socioletos, gírias, registros etc., durante o processo de tradução e em seu produto textual. Assim, é necessário que o tradutor reconheça as classes de variação linguística existentes e a forma como podem ser traduzidas para outra língua, isto é, há de levar em conta a diversidade linguística das línguas envolvidas na tradução.

A Sociolinguística, ao objetivar um retrato da gramática da língua, considera a interrelação dos aspectos linguísticos e extralinguísticos, assim como a Tradução Funcionalista. 
Ambas as áreas de estudos surgem em oposição às concepções formalistas de língua, portanto, compartilham a ideia de que a língua é um comportamento social e não pode ser vista isoladamente de seu contexto sócio-histórico-cultural de uso. Não obstante, observa-se que, tanto na Tradução Funcionalista quanto na Sociolinguística Variacionista, entender a função comunicativa de certo enunciado ou forma linguística utilizada, num determinado contexto, por um falante específico, tem relevância. Nessa perspectiva, atualmente, Paiva e Duarte (2006, p. 147) destacam que: “A associação entre pressupostos variacionistas e pressupostos funcionalistas se apoia essencialmente num ponto de partida comum: o de que a língua só pode ser entendida nos seus variados contextos de uso". Desta maneira, os estudos sobre variação linguística podem contribuir para a prática tradutória funcional, visto que a variação linguística também identifica grupos sociais e os estudos sociolinguísticos podem possibilitar ao tradutor o entendimento e a escolha adequada entre duas ou mais variantes de uma língua meta para um determinado encargo tradutório ou, ainda, para a compreensão do uso de uma determinada variante da língua-base a fim de traduzi-la à língua-meta.

Com esta breve seção, buscamos relacionar a Teoria Funcionalista com o Ensino de Línguas e a Sociolinguística Laboviana. A seguir, discorreremos sobre o procedimento de SD e a sua elaboração, a partir da Tradução Funcionalista de gêneros textuais autênticos para a abordagem da variação linguística.

\section{O procedimento de Sequências Didáticas a partir da Tradução Funcionalista}

Nessa seção, apresentamos sucintamente os procedimentos de elaboração da SD a partir da tradução funcionalista. Para tanto, cabe definir o que é uma SD, a qual entendemos como uma série de atividades organizadas, de maneira sistemática, em torno de um gênero textual oral ou escrito (DOLZ; NOVERRAZ; SCHNEUWLY, 2004, p. 96). Para os autores, quando os usuários de uma língua se comunicam, adaptam-se à situação comunicativa e, quando interagem em situações parecidas, escrevem/falam textos com características semelhantes, os quais são considerados gêneros textuais, "conhecidos de e reconhecidos por todos, e que, por isso, facilitam a comunicação.” (DOLZ; NOVERRAZ; SCHNEUWLY, 2004, p. 97). Assim, para os autores, o objetivo de uma SD é a apropriação de um gênero textual, os quais podem ser entendidos como:

PONTES; PEREIRA. A construção dos módulos de uma sequência didática a partir da tradução funcionalista para o ensino da variação linguística 
[...] como uma noção propositalmente vaga para referir os textos materializados que encontramos em nossa vida diária e que apresentam características sociocomunicativas definidas por conteúdos, propriedades funcionais, estilo e composição característica. Se os tipos textuais são apenas meia dúzia, os gêneros são inúmeros. (MARCUSCHI, 2010, p. 23)

Sobre a organização de uma SD, Barros (2014) alude a, pelo menos, cinco etapas, as quais são: i) apresentação de um problema de comunicação; ii) primeira produção do gênero; iii) oficinas ou módulos didáticos; iv) nova produção; v) processo de Reescrita textual. No esquema a seguir, resumimos as características de tais etapas:

Figura 1 - Organização de uma SD, segundo Barros (2014)

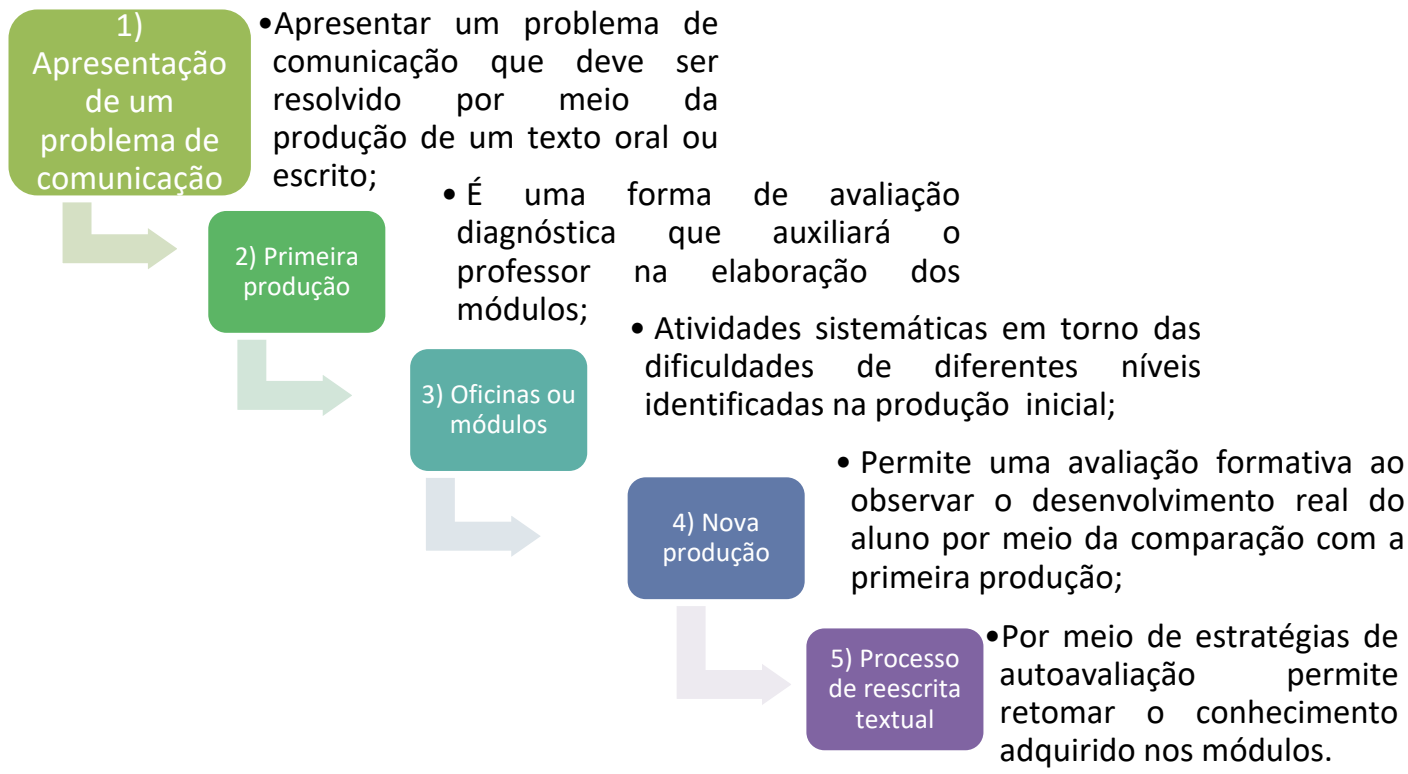

Fonte: Adaptado de Barros (2014).

Ao realizar uma SD a partir da tradução funcional de um gênero textual autêntico, propomos algumas modificações na sequência dessas etapas. Por exemplo, a etapa de apresentação da situação inicial corresponderá a amostras de traduções do gênero determinado que circulam socialmente, além da apresentação de um texto a ser traduzido e um encargo de tradução didático. Conforme Nord (1996), o encargo de tradução deve especificar a função ou as funções comunicativas que a tradução deve alcançar, além de determinar os receptores do TM, as condições temporais e espaciais previstas para a recepção da tradução, o meio pelo qual será transmitida e o propósito da tradução. A partir dessa primeira etapa, elabora-se a produção 
inicial, a qual será vista pelo professor-pesquisador como um diagnóstico acerca do domínio do gênero textual pelos alunos e de suas capacidades de linguagem (BARROS, 2012, p. 82).

A produção inicial, na SD com a tradução funcionalista, pode ser baseada em uma análise do TB a partir do modelo de análise pré-tradutória de Nord (2012), o qual expomos na seção anterior e permite analisar as características intra e extratextuais do TB e do TM, mediante um encargo de tradução determinado. Esse modelo de análise possibilitará ao aprendiz pesar os elementos que devem ser adaptados à cultura do receptor do TM e, com essas informações, poderá escrever uma primeira produção do TM. A etapa da análise pré-tradutória de Nord (2012), antes da primeira produção, coincide com o que Costa-Hürbes e Simioni (2014, p. 26) chamam de Módulo de Reconhecimento, uma adaptação do esquema de SD suíço à vertente brasileira. Nessa etapa, as autoras definem que é feita uma pesquisa, leitura e análise linguística do gênero a ser produzido, aspectos proporcionados pelo modelo de análise de Nord (2012).

Com base nas dificuldades apresentadas pelos alunos ao realizarem a primeira produção do gênero textual em uma SD, são elaborados os módulos. Esses, segundo Cristóvão (2009, p. 310), dependem das capacidades dos alunos, do nível escolar, do currículo e do gênero trabalhado. Não há uma quantidade limite de módulos que possam ser realizados em uma SD, podendo variar de acordo com o contexto de ensino, a disponibilidade de tempo, os objetivos da SD, etc. Na visão de Barros (2012, p.82), os módulos devem abordar problemas de diferentes níveis (apresentação da situação de comunicação, aprofundamento temático, infraestrutura do gênero, etc.), além de propostas e exercícios variados, desde questões de observação e análise de textos a prática de leitura, oralidade, audição, etc. Também, podem-se intercalar atividades com outros gêneros, e, ao fim de cada módulo realizado, a autora sugere a elaboração de listas de constatações do que foi aprendido.

No caso dos módulos de uma SD com o uso da tradução funcionalista, esses serão baseados nas dificuldades apresentadas pelos aprendizes durante a análise textual pré-tradutória de Nord (2012) e na primeira produção do TM. Assim, se, por exemplo, os aprendizes mostrarem dificuldades no que tange à identificação da composicionalidade do TB e do TM, elaborar-se-ão módulos específicos sobre o gênero textual que está sendo traduzido. Ou, ainda, se os aprendizes mostrarem dificuldades na adequação linguística do TM ao público meta do encargo de tradução, planejar-se-ão módulos específicos acerca dos aspectos linguísticoculturais relacionados à adequação. Por sua vez, poderá haver módulos específicos para os problemas de tradução, identificados na análise pré-tradutória de Nord (2012).

PONTES; PEREIRA. A construção dos módulos de uma sequência didática a partir da tradução funcionalista para o ensino da variação linguística 
Após a execução dos módulos, propõe-se a reescrita da primeira produção, a qual, nas palavras de Cristóvão (2009, p. 311): "se caracteriza como o lugar de integração dos saberes construídos e de instrumentos apropriados". Essa nova produção pode ser comparada à primeira produção, o que permitirá ao professor uma avaliação do desenvolvimento real do aluno e uma avaliação formativa (BARROS, 2012, p. 82). Logo, no tocante à SD com o uso da tradução funcionalista, será proposta uma reescrita da primeira produção do TM, que constituirá a versão final. Espera-se que tal produção seja funcional na situação-em-cultura, determinada no encargo de tradução didático, proposto para a SD. Na prática de uma SD: "O aluno deve aprender que escrever é (também) reescrever. A estruturação da SD em primeira produção, por um lado, e produção final, por outro, permite tal aprendizagem" (DOLZ; NOVERRAZ; SCHNEUWLY, 2004, p.113).

No que diz respeito à aplicação desse procedimento, elaboramos uma SD que foi realizada na disciplina "Introdução aos Estudos da Tradução em Língua Espanhola" (2º semestre), ofertada de forma optativa, pela coordenação do Curso em Letras Língua Espanhola e suas Literaturas, de uma universidade pública. A disciplina tinha a carga horária total de 32 184 horas, resultando em um encontro semanal, durante 16 semanas. A escolha por alunos(as) matriculados(as) nessa disciplina resultou da aproximação temática desta com os objetivos da pesquisa. Ademais, essa disciplina consistiu no Estágio de Docência da própria pesquisadora. Assim, todo o procedimento da SD foi guiado por ela durante a metade da mesma, isto é, 8 semanas (16 h/a). Por ser uma disciplina optativa, estudantes de outros semestres puderam participar dela, mas para a análise da pesquisa somente foram considerados os resultados de: 1 . aprendizes brasileiros de Língua Espanhola sem parentes de origem hispânica em primeiro grau; 2. estudantes em nível A2 (segundo semestre do curso de graduação); 3. estudantes de ambos os sexos, com o Português Brasileiro como Língua Materna; 4. estudantes regularmente matriculados na disciplina; 5. estudantes que concordaram, de livre e espontânea vontade, em participar da pesquisa, assinando o Termo de Consentimento Livre e Esclarecido exigido pelo Comitê de Ética.

Vale ressaltar que, para a SD, a turma foi dividida em 8 grupos de 4 ou 5 estudantes, visando a uma escrita colaborativa, com o foco no processo e não no produto. Para além disso, selecionamos cinco peças teatrais hispânicas como TB dos grupos, a partir dos seguintes critérios: a) peças teatrais de diferentes países hispânicos, apresentando casos de variação linguística nas formas de tratamento, de acordo com a divisão de Fontanella de Weinberg 
$(1999)^{7}$; b) período histórico de publicação da obra (segunda metade do século XIX ou primeira metade do século XX); c) gênero comédia; d) extensão (50 a 60 páginas); e) disponibilidade na internet. Além disso, os fragmentos de cada peça foram selecionados por meio da frequência das formas de tratamento pronominais e da relevância do fragmento para o enredo da peça teatral. A seguir, expomos as peças escolhidas:

Quadro 2 - Peças teatrais selecionadas para a SD

\begin{tabular}{|c|c|c|c|c|c|}
\hline & El nido & El héroe & La pobre & Pueblecito - & Los Mirasoles \\
Obra / Autor/ & ajeno - & galopante - & gente - & Armando & - Julio \\
Ano & Jacinto & Nemesio C. & Florencio & Mook (1918) & Sánchez \\
& Benavente & Canales & Sánchez & & Gardel (1911) \\
& $(\mathbf{1 8 9 4 )}$ & $(\mathbf{1 9 2 3 )}$ & $\mathbf{( 1 9 0 4 )}$ & & \\
\hline
\end{tabular}

Fonte: PEREIRA, 2016.

Por outro lado, seguindo as diretrizes propostas por Nord (1996), o encargo de tradução didático consistiu no blog intitulado "Traduciendo el Teatro Hispánico" (http://traduccionyteatrohispanico.blogspot.com.br/), criado pela pesquisadora, a fim de contemplar o princípio da comunicabilidade. Também apresentamos as seguintes informações aos grupos: 1. Função comunicativa do TM: adaptar obras teatrais hispânicas de comédia para o entretenimento do público brasileiro adulto atual; 2. Destinatários do TM: brasileiros de diferentes regiões do país; 3. Condições temporais e locais de recepção do TM: século XXI, ano 2016, Brasil; 4. Meio de transmissão do TM: ambiente virtual blog; 5. Motivo: divulgar antigas obras teatrais hispânicas para o público brasileiro, na internet.

A partir desse encargo tradutório, cada grupo selecionou um fragmento de peça teatral para traduzir, além de eleger uma das cidades brasileiras, sugeridas pela pesquisadora, como o seu público-meta. As cidades sugeridas foram escolhidas a partir da divisão dos subsistemas de tratamento pronominais, proposta por Scherre et al. (2015). Assim, pontuamos: Fortaleza (Região Nordeste - Subsistema “tu/você com concordância média”); Belém do Pará (Região Norte - Subsistema “mais tu com concordância alta”); São Paulo (Região Sudeste - Subsistema "só você"); Brasília (Região Centro-Oeste - Subsistema "você/tu sem concordância") e Florianópolis (Região Sul - Subsistema "mais tu com concordância alta”).

Vale destacar que, ao elaborar a SD com a tradução do gênero peça teatral de comédia, realizamos o Modelo Didático do Gênero, com base em Cristóvão (2010) e Barros (2012), o qual serviu como norte para a elaboração da Grade de Análise Diagnóstica da Primeira Tradução, além de auxiliar a composição dos módulos e a lista de constatações. Entretanto, 
devido aos limites de extensão deste artigo, não expusemos tais elementos. Em relação à análise pré-tradutória, essa consistiu em um módulo de reconhecimento do gênero, antes da primeira tradução, através da qual constatamos dificuldades relacionadas à identificação do receptor, lugar, função, conteúdo, composição e aspectos suprassegmentais, no TB e no TM. Dentre esses aspectos, na Primeira Tradução também observamos dificuldades no que se refere à adaptação do TM ao receptor e lugar de recepção (capacidades de ação), à planificação e organização do gênero (capacidades discursivas) e à adaptação do TM à gramática, vocabulário e ortografia, falha na adequação da tradução das formas de tratamento pronominais de acordo com a origem de seu público-meta, além da generalização das relações sociais entre as personagens, por meio do uso da forma "você" (capacidades linguístico-discursivas).

A partir das dificuldades elencadas, propomos os módulos da SD, dos quais apresentamos um breve recorte na próxima seção.

\section{Construindo os Módulos da SD com a Tradução Funcionalista do Gênero Comédia}

\section{Teatral}

De acordo com Cristóvão (2009), a quantidade de módulos realizados em uma SD é guiada a partir da disponibilidade de tempo, do contexto de ensino e dos objetivos da SD. Assim, devido a esses fatores, propusemos dez módulos, dentre os quais dois foram realizados como Módulos de Reconhecimento, antes da primeira tradução (COSTA-HÜRBES; SIMIONE, 2014), e outros 8 foram realizados após a primeira tradução. De forma resumida, apresentamos os objetivos de cada módulo, a seguir:

Quadro 3 - Módulos da SD Final

Módulos

Módulo 1: Conociendo el género textual teatro

Módulo 2: Lectura y Análisis pretraslativo de los fragmentos de piezas teatrales hispánicas

\begin{tabular}{cc|l} 
Módulo & 3: Lectura y & Refletir acerca das diferentes características composicionais do texto \\
análisis & de obras & teatral, brasileiro e hispânico, nos séculos XIX e XXI, incluindo o tipo
\end{tabular} teatrales hispánicas $y$ de linguagem (formal, informal, etc.), o objetivo, o assunto, a sequência brasileñas

Módulo 4: Organización general de las piezas teatrales

\section{Descrição dos objetivos e capacidades de linguagem envolvidas}

Ter contato com as principais características do gênero peça teatral, por meio do vídeo "História del teatro - Elementos del Teatro" (www.youtube.com/watch?v=pntToe9VLW4). Aborda as capacidades de ação, no que tange à recepção e produção do texto teatral, além das capacidades discursivas acerca das grandes partes do texto teatral.

Analisar a situação de recepção do TM, além das características extra e intratextuais dos fragmentos de peças teatrais para tradução. Envolve todas as capacidades de linguagem (Figura 7).

textual etc. Engloba as capacidades de ação, discursivas e linguísticodiscursivas.

Reconhecer os elementos constituintes do gênero peça teatral, (título, lista de personagens, divisão de atos, etc.); distinguir expressões usadas para iniciar, manter ou encerrar um diálogo e utilizá-las para produzir 


\begin{tabular}{|c|c|}
\hline & $\begin{array}{l}\text { uma cena teatral, em Espanhol. Engloba as capacidades discursivas, } \\
\text { linguístico-discursivas e de ação. }\end{array}$ \\
\hline $\begin{array}{l}\text { Módulo 5: Pronombres } \\
\text { de Tratamiento en } \\
\text { Contexto }\end{array}$ & $\begin{array}{l}\text { Identificar os pronomes de tratamento para } 2^{\mathrm{a}} \text { pessoa em Língua } \\
\text { Espanhola; refletir sobre seus usos e sua tradução para o Português } \\
\text { Brasileiro. Aborda capacidades linguístico-discursivas. }\end{array}$ \\
\hline $\begin{array}{l}\text { Módulo 6: Búsquedas de } \\
\text { información para } \\
\text { traducir }\end{array}$ & $\begin{array}{l}\text { Investigar as formas e usos dos pronomes de tratamento para } 2^{\mathrm{a}} \text { pessoa } \\
\text { utilizados nos países das peças teatrais hispânicas e nas cidades } \\
\text { brasileiras que receberão o TM. Capacidades de ação e linguístico- } \\
\text { discursivas. }\end{array}$ \\
\hline $\begin{array}{l}\text { Módulo 7: Variación en } \\
\text { el sistema de tratamiento } \\
\text { pronominal en Español } \\
\text { (Argentina, } \\
\text { España, Puerto Rile, } \\
\text { Uruguay) }\end{array}$ & $\begin{array}{l}\text { Explorar a evolução histórica e examinar os condicionamentos de uso } \\
\text { das formas de tratamento para } 2^{\mathrm{a}} \text { pessoa na Língua Espanhola (origem } \\
\text { geográfica, período histórico, relação entre interlocutores, situação de } \\
\text { comunicação). Aciona capacidades linguístico-discursivas. }\end{array}$ \\
\hline 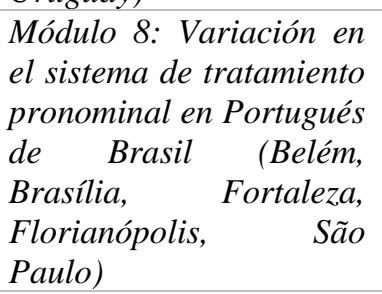 & $\begin{array}{l}\text { Explorar a evolução histórica e examinar os condicionamentos de uso } \\
\text { das formas de tratamento para } 2^{\mathrm{a}} \text { pessoa no Português Brasileiro } \\
\text { (período histórico, relações entre os interlocutores, origem geográfica). } \\
\text { Aciona capacidades linguístico-discursivas. }\end{array}$ \\
\hline $\begin{array}{l}\text { Módulo 9: Análisis de la } \\
\text { variación en los usos de } \\
\text { las formas de tratamiento } \\
\text { en piezas teatrales y } \\
\text { traducción }\end{array}$ & $\begin{array}{l}\text { Relacionar os sistemas de tratamento pronominais da Língua Espanhola } \\
\text { (FONTANELLA DE WEINBERD, 1999) com trechos de peças teatrais } \\
\text { hispânicas; reconhecer o sistema de tratamento pronominal utilizado no } \\
\text { fragmento de tradução. Uso de capacidades de ação e linguístico- } \\
\text { discursivas. }\end{array}$ \\
\hline $\begin{array}{l}\text { Módulo 10: traducción } \\
\text { Español-Portugués } \\
\text { lenguaje, formas de } \\
\text { tratamiento y variación } \\
\text { lingüística en obras } \\
\text { teatrales }\end{array}$ & $\begin{array}{l}\text { Traduzir um pequeno trecho da peça teatral destinada à equipe, tendo em } \\
\text { vista a cidade brasileira receptora do TM. Envolve todas as capacidades } \\
\text { de linguagem. }\end{array}$ \\
\hline
\end{tabular}

Fonte: PEREIRA, 2016.

Em cada módulo, buscamos integrar as diferentes capacidades de linguagem. No entanto, diante do objetivo central da pesquisa acerca da variação nas formas de tratamento pronominais para $2^{\mathrm{a}}$ pessoa, a maior parte dos módulos contemplou as capacidades linguísticodiscursivas. Essa atitude também justifica-se no resultado da Grade de Análise Diagnóstica da Primeira Tradução, que mostra maior dificuldade dos participantes em relação à adaptação da gramática e vocabulário do Português Brasileiro e à adequação da tradução das formas de tratamento, a partir do receptor do TM e das relações sociais estabelecidas entre as personagens do TB.

Os dois primeiros módulos já foram abordados na primeira seção deste capítulo. Ambos foram realizados antes da primeira tradução como forma de ativar os conhecimentos prévios acerca do gênero e de suas características. O terceiro e o quarto módulos se basearam nas dificuldades identificadas através da Análise pré-tradutória de Nord (2012), Módulo 2, e confirmadas na Grade de Análise Diagnóstica da Primeira Tradução, a saber: identificação do 
receptor e lugar de recepção, função do TB/TM e tema (capacidades de ação), composicionalidade do gênero (capacidades discursivas) e unidades linguísticas básicas na sequência dialogal (capacidades de linguagem). No quinto e no sexto módulos, abordamos a variação linguística no uso das formas de tratamento na Língua Espanhola, buscando sensibilizar os participantes acerca dos diferentes usos dessas formas e as suas implicações, além de refletir sobre a sua tradução ao Português Brasileiro de distintas regiões.

Por sua vez, no sétimo e no oitavo módulos, tratamos com maior especificidade da variação diatópica, diacrônica e diafásica das formas de tratamento nas variedades da Língua Espanhola e do Português Brasileiro, tendo em vista que os grupos apresentaram dificuldades na adequação da forma de tratamento, no TM, de acordo com a origem geográfica do receptor e das relações sociais representadas no TB. A partir do nono módulo, buscamos averiguar se os grupos reconhecem os diferentes usos e formas de tratamento da Língua Espanhola, a partir da análise de pequenos trechos das peças teatrais utilizadas na SD. Formulamos esse módulo a partir da divisão do sistema de tratamento pronominal de Fontanella de Weinberg (1999), incluindo tanto as capacidades linguístico-discursivas quanto as capacidades de ação, já que é 188 necessário compreender o contexto sócio histórico dos trechos para identificar os usos das formas de tratamento.

No décimo módulo, solicitamos a tradução para o Português Brasileiro do mesmo trecho utilizado no Módulo 9, referente a cada grupo, a fim de integrar os conhecimentos dos demais módulos, sobre as formas de tratamento e as características do gênero peça teatral. A partir da formulação desses módulos, apresentamos a versão final da nossa SD:

PONTES; PEREIRA. A construção dos módulos de uma sequência didática a partir da tradução funcionalista para o ensino da variação linguística 
Figura 2 - Versão Final da SD

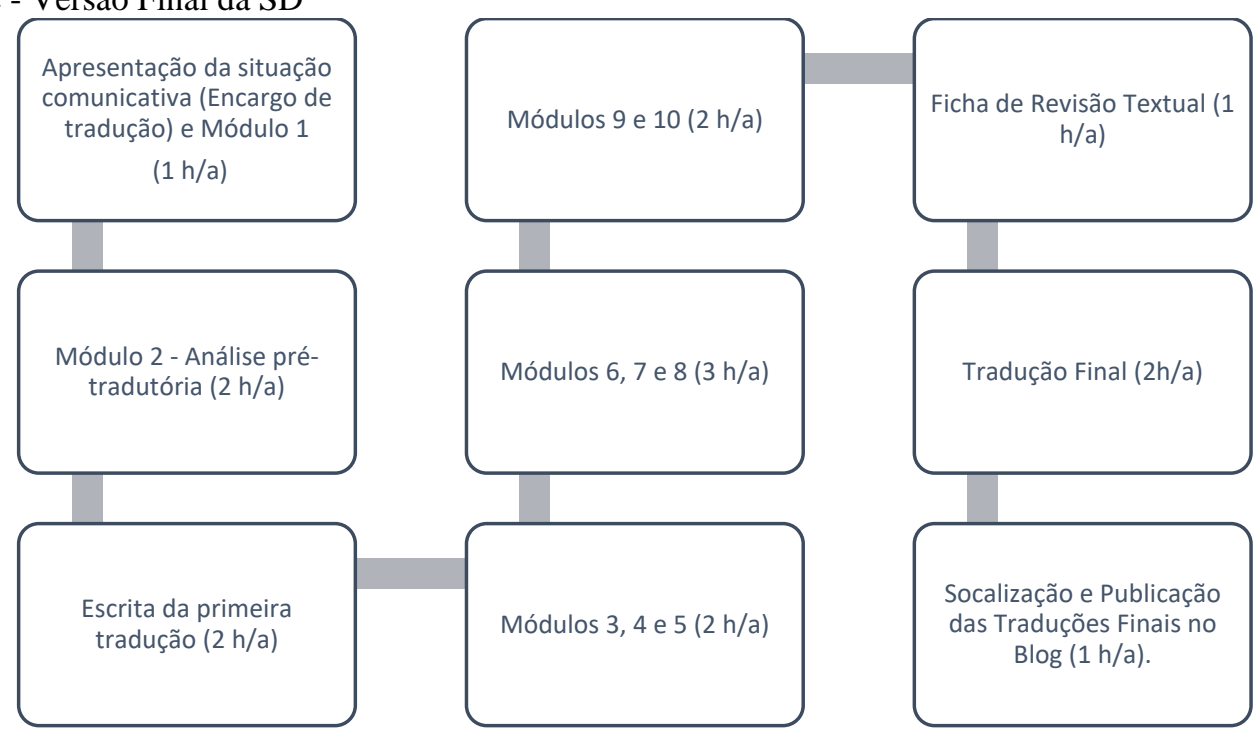

Fonte: PEREIRA, 2016.

Esclarecidos os objetivos de cada módulo e apresentada a versão final da SD, a seguir, analisamos as respostas obtidas nos módulos 4, 5 e 8. Escolhemos estes módulos devido à abordagem da organização textual do gênero peça teatral, além das variações linguísticas nas formas de tratamento pronominais da Língua Espanhola e Portuguesa. Assim, no que tange ao Módulo 4, este está composto por 4 questões. A primeira delas mobilizou as capacidades discursivas, ao solicitar que os grupos relacionassem os nomes de cada elemento constitutivo da peça teatral de comédia com as respectivas imagens, tais como: monólogo, diálogo, rubricas, atos ou cenas, título, etc. Notamos que os grupos não tiveram dificuldades em relacionar tais elementos, realizando as associações esperadas, conforme a Figura 3.

Figura 3 - Respostas do G-II ao Módulo 4

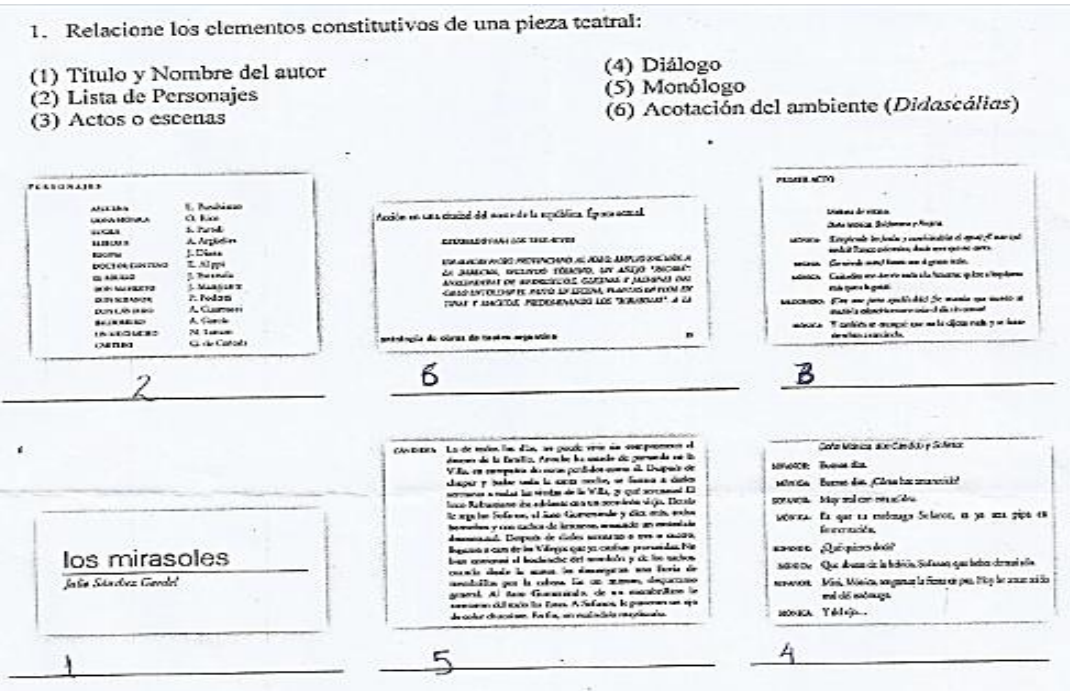

Fonte: Grupo II, Pereira (2016).

PONTES; PEREIRA. A construção dos módulos de uma sequência didática a partir da tradução funcionalista para o ensino da variação linguística

Belas Infiéis, v. 7, n. 1, p. 175-200, 2018. 
$\mathrm{Na}$ segunda questão desse módulo, foram mobilizados conhecimentos linguísticodiscursivos, ao pedir que os grupos apontassem expressões, utilizadas em um fragmento de peça teatral, que servissem para iniciar, encerrar ou manter uma conversa. Em geral, as expressões apontadas para começar um diálogo foram: “Buen día!” e "Mañanita fresquita ¿eh?”; por sua vez, todos os grupos pontuaram a expressão "Hasta mañana" para encerrar a conversação e expressões como "Usted sabe...", "Vas a tener?", "Ya me debes..." foram destacadas para continuar um diálogo. Em forma de ilustração, na Figura 16, expomos as respostas do G-II, a seguir:

Figura 4 - Respostas do G-II à segunda questão do Módulo 4

2. Lea el diálogo, a seguir, e identifique los interlocutores y la relación que poseen. Luego,escribe en las columnas los elementos del diálogo que se piden:

\begin{tabular}{|c|c|c|}
\hline $\begin{array}{l}\text { Expresiones de apertura de una } \\
\text { conversación (de carácter fático: Hola, } \\
\text { Buenos Días, Por favor, ¿Qué tal?, etc.) }\end{array}$ & $\begin{array}{l}\text { Expresiones de cierre de conversación } \\
\text { (Adiós, Hasta luego, Me voy, etc.) }\end{array}$ & $\begin{array}{l}\text { Expresiones interacciónales (tales } \\
\text { como, pregunta-respuesta, yocativos, } \\
\text { Frases hechas, exclamaciones, etc.) }\end{array}$ \\
\hline $\begin{array}{l}\text { Buen dia } \\
\text { mañanita Fresquita }\end{array}$ & $\begin{array}{l}\text { Hasta mañana } \\
\text { i Andando! } \\
\text { A vet si mañana }\end{array}$ & $\begin{array}{l}\text { Givenos } \\
\text { Usted sabe. } \\
\text { Vas a tener }\end{array}$ \\
\hline
\end{tabular}

190 Fonte: Grupo II, Pereira (2016).

Na terceira questão desse módulo, solicitamos que os grupos reconhecessem as marcas tipográficas utilizadas na identificação das rubricas. Essa questão se baseou na dificuldade apresentada pelos grupos em reconhecer as rubricas ou didascálias como parte da composição do gênero, na análise pré-tradutória. Os grupos reconheceram que os parênteses, letras maiúsculas, em negrito ou itálico, ajudam a identificar as rubricas, as quais foram circuladas no fragmento textual apresentado.

Figura 5 - Questão 3 e 4 do módulo 4 do G-II

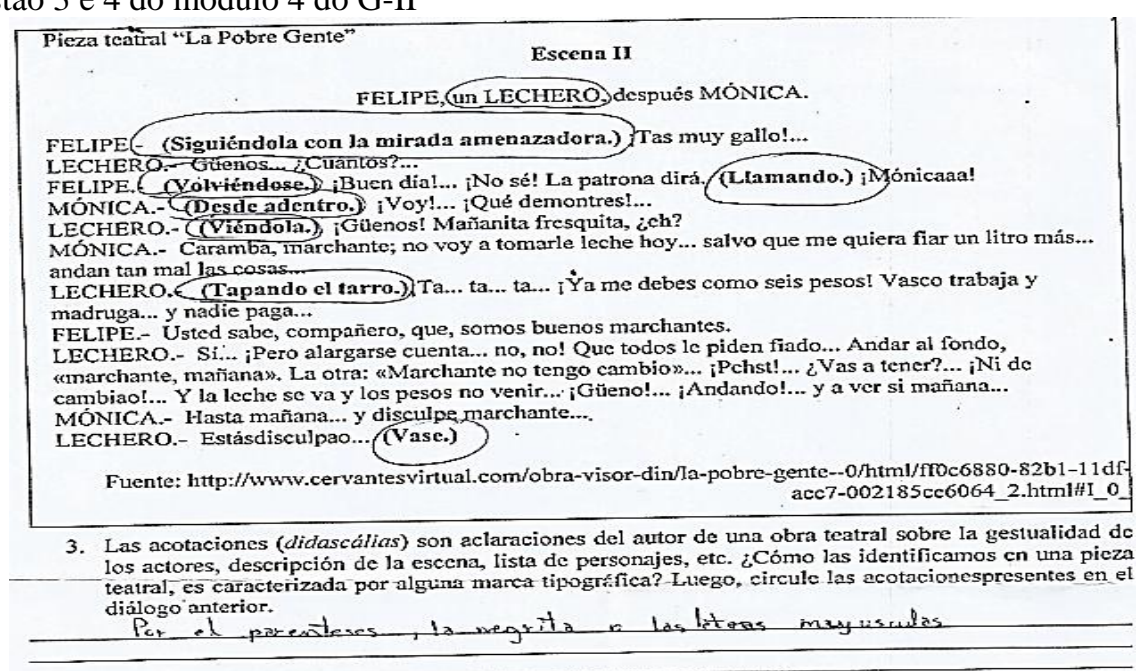

Fonte: Grupo II, Pereira (2016).

PONTES; PEREIRA. A construção dos módulos de uma sequência didática a partir da tradução funcionalista para o ensino da variação linguística

Belas Infiéis, v. 7, n. 1, p. 175-200, 2018. 
No entanto, apesar de reconhecerem as rubricas no texto, ao realizar a quarta questão e criar uma cena teatral, somente o G-IV apresentou algumas rubricas em seu texto, conforme expomos na Figura 6. A quarta questão, por solicitar a escrita de uma cena teatral, envolve as capacidades de ação (mobilizando os elementos contextuais para formulação do texto), discursivas (mobilizando os conhecimentos sobre a composicionalidade, coesão e coerência do texto) e linguístico-discursivas (mobilizando os elementos linguísticos de forma adequada).

Figura 6 - Resposta do G-IV a quarta questão do Módulo 4

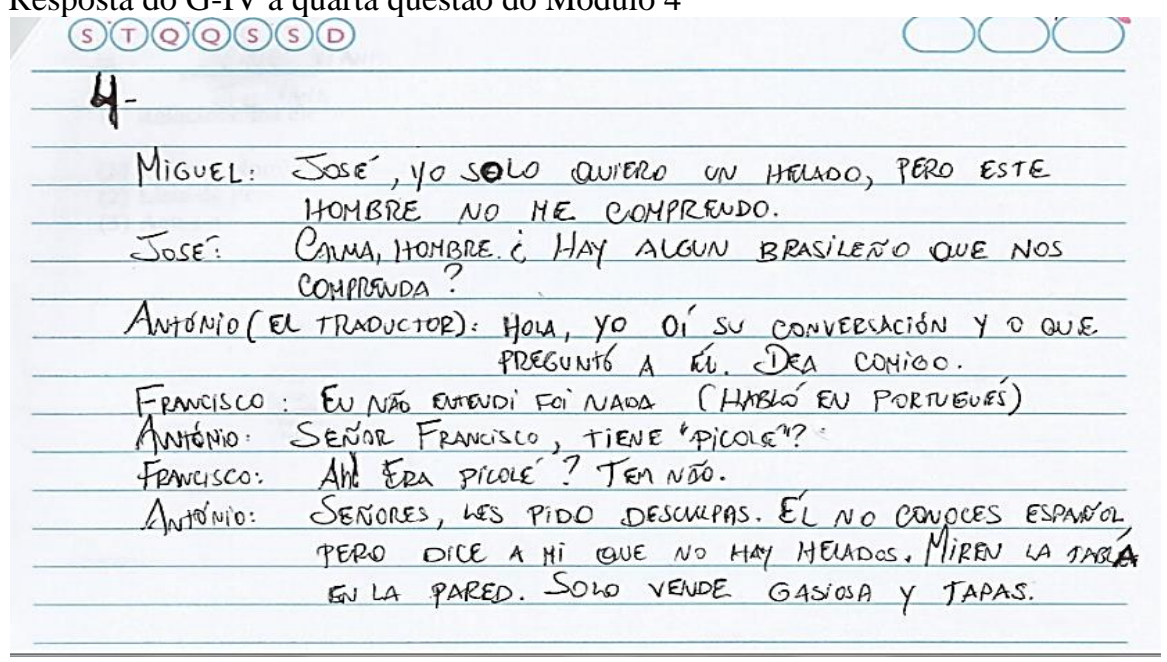

Fonte: Grupo IV, Pereira (2016).

Em seu turno, o Módulo 5 explora especificamente as capacidades linguísticodiscursivas, ao tratar das formas de tratamento para $2^{\mathrm{a}}$ pessoa na Língua Espanhola. Esse módulo tem apenas uma questão com quatro itens e baseia-se na leitura e análise de um fragmento de peça teatral chileno. No item A, os grupos identificam as formas de tratamento pronominais utilizadas no texto, as quais foram: "señor", "usted", "tú" e "vos"; e pontuam por quais formas poderiam ser traduzidas para o Português Brasileiro. Sobre as opções de tradução, o G-I e o G-III pontuaram as formas de tratamento "senhor", "você” e "tu”. Já o G-II e o G-IV, além dessas formas, citaram o pronome "vós", fato que indica que esses dois grupos podem não ter compreendido os usos do "vos" chileno, um tratamento para $2^{\mathrm{a}}$ pessoa do singular utilizado, geralmente, em contexto íntimo e informal e, quando utilizado em sua forma completa, possui conotações rurais (CALDERÓN CAMPOS, 2010). 
Figura 7 - Respostas ao Módulo 5 do grupo G-IV, item A

a) ¿Cuál(es) la(s) forma(s) de tratamiento para el trato de segunda persona del discurso encontradas en el fragmento anterior? Y, ¿por cuál(es) forma(s) de tratamiento se podrían traducir al portugués según el contexto?

Señon, usted, vos, tw. Senhor, voci, wos, tw

Fonte: Grupo IV, Pereira (2016).

No item B do Módulo 5, os grupos são indagados se, no texto apresentado, há mudanças de formas de tratamento e se essas são influenciadas por algum fator. Com esse item, objetivamos que os grupos refletissem sobre as formas de tratamento da Língua Espanhola e os seus condicionamentos. O G-I e o G-III deram respostas mais completas a esse item, indicando a relação de intimidade ou formalidade entre as personagens do texto e o uso das formas de tratamento. Por outro lado, o G-II e o G-IV esboçaram respostas mais concisas, apenas citando fatores que podem influenciar a escolha das formas de tratamento, tais como: a familiaridade, a proximidade ou distância e a diferença etária. Por meio dessas respostas, notamos que os grupos não identificaram o fator geográfico como condicionante do uso das formas de tratamento, destacando apenas os condicionamentos diafásicos (formalidade, informalidade) e diastrásticos (idade).

Figura 8 - Respostas ao Módulo 5, do G-IV, Itens B, C e D

b) ¿Hay cambios de formas de tratamiento entre los interlocutores en el texto 1 ? Si hay, ¿cuáles son y qué aspectos pueden haber influido en la elección de una forma u otra de tratamiento pronominal?

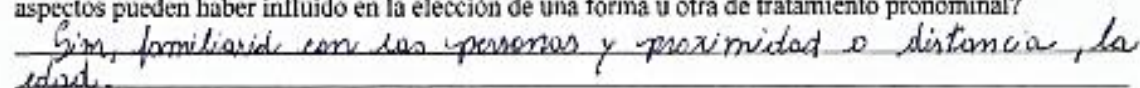

c) ¿Las formas de tratamiento cncontradas en el texto 1 también se encuẹntran en el fragmento de pieza teatral para tradueción de su grupo? Ejemplifiquen.

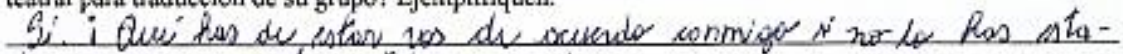
do nuras con el suthido cornin!

d) En la opinión del grupo, si en el fragmento de pieza teatral que van a traducir hay cambios de pronombres de tratamiento iseria posible mantener los cambios de tratumiento en la traducción hacia el portugués brasileño? Justifiquen.

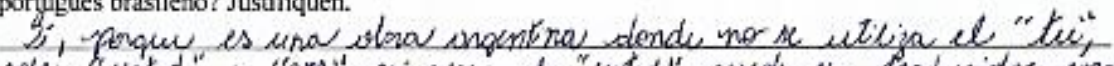

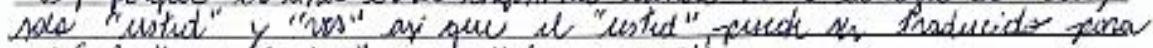
Fonte: Grupo IV, Pereira (2016).

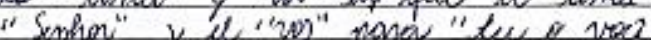

Nos itens C e D, buscamos sensibilizar os grupos acerca da tradução das formas de tratamento. No item C, os grupos indicaram a presença dessas formas no seu TB e deram exemplos. Já no item D, indagamos se havia alternância das formas de tratamento no TB e se essas alternâncias poderiam ser mantidas no TM. Em geral, os grupos reconheceram, nesse 
item, que poderiam manter as alternâncias de tratamento. Por exemplo, na resposta do G-IV (Figura 8), o grupo argumenta que seria possível manter as alterações pronominais, uma vez que, no TB argentino, apresentava-se somente o "vos" e o "usted", os quais poderiam ser traduzidos, respectivamente por "tu ou você" e "senhor". Esse grupo foi consistente, na sua justificativa, por atentar para o sistema de tratamento típico argentino, embora não tenha mencionado ou refletido sobre o sistema de tratamento da região do seu público-meta.

Quanto aos demais grupos, o G-I indicou que seria possível manter as mudanças de pronomes, no TM, e que elas ocorrem a partir da oposição formalidade x informalidade. Em contrapartida, o G-II argumentou que, às vezes, poderia manter as alternâncias de tratamento, já que, no século XXI, não se utiliza uma linguagem tão formal quanto nos séculos passados. Assim, pontuaram que o "usted" também poderia ser traduzido pela forma "tu”. Vejamos:

Figura 9 - Resposta do G-II ao item D do Módulo 5

d) En la opinión del grupo, si en el fragmento de pieza teatral que van a traducir hay cambios de pronombres de tratamiento ¿sería posible mantener los cambios de tratamiento en la traducción hacia el portugués brasileño? Justifiquen.

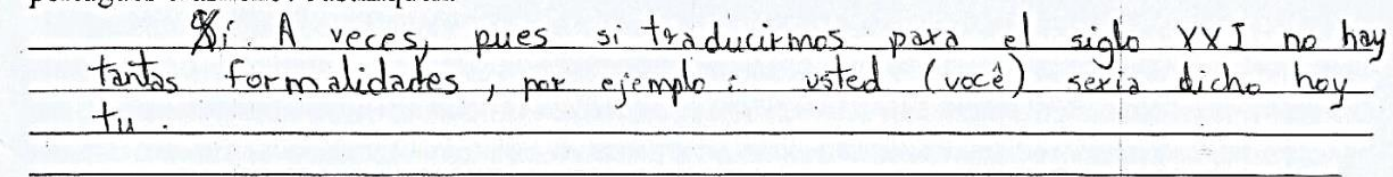

Fonte: Grupo II, Pereira (2016).

O G-III concorda que, no TM, há possibilidades de manter a alternância nas formas de tratamento, já que as regras de tratamento são parecidas com as do Português, em que podemos tutear as pessoas mais próximas e ser mais formais com as demais pessoas. Esse grupo, no entanto, não leva em consideração que há regiões do Brasil onde a forma "você" é de uso estendido, com pouco ou nenhum uso da forma "tu" (SCHERRE et al., 2015). Assim, por meio dessas respostas, podemos constatar que, apesar de os grupos reconhecerem que poderiam manter as alternâncias de tratamento, conforme a Análise Diagnóstica da Primeira Tradução realizada anteriormente, a maioria dos grupos generalizou essas alternâncias de tratamento, utilizando apenas a forma "você".

Por fim, para finalizar esta seção, expomos a análise do módulo 8, o qual abordou especificamente a variação linguística nos usos das formas de tratamento pronominais no português brasileiro. Assim, nesse módulo, versamos sobre a variação diacrônica, diatópica e diafásica nas formas de tratamento do Português Brasileiro, centrando-nos nas capacidades linguístico-discursivas. O módulo está composto por três questões. Na primeira delas, por meio 
da leitura de um fragmento do texto de Menon (1995), os grupos identificaram a evolução histórica dos usos das formas "vós", "tu" e "você". De forma geral, elencaram que: 1. o pronome "vós" era uma forma polida de tratamento que poderia ser usada no singular ou plural e, atualmente, encontra-se em desuso; 2. a forma de tratamento "tu" era usada em situações informais, entre interlocutores íntimos e conhecidos, no polo de inferioridade e, nos dias de hoje, continua sendo uma forma íntima e informal usada em algumas regiões do Brasil; 3. o pronome "você", originalmente, utilizado como uma forma respeitosa para tratar superiores, hoje em dia é usado em situações informais, coocorrendo com a forma "tu" em diversas regiões brasileiras.

A segunda questão trata da variação diatópica através do vídeo "Jornal Hoje - Sotaques do Brasil mostra os jeitos diferentes de falar brasileiro". ${ }^{8} \mathrm{O}$ vídeo discorre sobre o uso de "tu" e "você" nas regiões brasileiras e, por meio dele, elaboramos dois itens. No item A, os grupos identificaram que havia regiões em que a forma "você" é predominante, como nas regiões Centro-Oeste e Sudeste, e em outros locais essa forma coocorre com o pronome "tu", conforme a Figura 10, a seguir. No item B, os grupos mencionaram que as regiões Sul, Norte e Nordeste 194 são as que mais utilizam a forma "tu" em contextos informais.

Figura 10 - Respostas do G-III à segunda questão do Módulo 8

2. Veanelreportaje "Jornal Hoje - Sotaques do Brasil mostra os jeito diferentes de falar brasileiro." (https://www.youtube.com/watch?v=HwHfkuRCflc) y contesta a las preguntas:

a) ¿Todas las regiones brasileñas utilizan el "tu" y el "você" de igual modo? ¿Por qué?

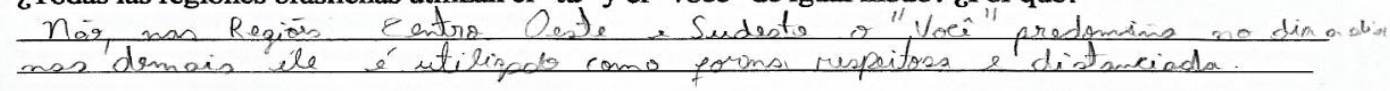

b) Según el reportaje, ¿cuáles son las regiones brasileñas que más utilizan el "tu” ¿En qué contextos se lo utiliza?

$\frac{\text { Regià Sul, nonte a nodeste. Se utilinp am realocos de }}{\text { proximidsde }}$

Fonte: Grupo III, Pereira (2016).

Em seu turno, na última questão desse módulo, expusemos fragmentos de conversação, retirados de pesquisas sociolinguísticas sobre o uso das formas de tratamento, e pedimos que os grupos respondessem a três itens. No item A, de forma geral, os grupos apontaram que, nas Regiões Centro-Oeste e Sudeste, havia o uso da forma "você" e sua variante "cê", embora, no trecho brasiliense, também tenha ocorrido a forma "tu", conforme ilustramos, por meio das respostas do G-III: 
Figura 11 - Respostas do G-III à terceira questão do Módulo 8

A) En muchas regiones brasileñas el "você" es de uso predominante para las situaciones de intimidad o informalidad. Entre los fragmentos de conversaciones presentados, en cuáles se presentó el pronombre "você" y sus variantes como forma de tratamiento? Además, ¿hay alternancias con el pronombre "tu"?

Regió centro Oeste e Resjōo Sudeste. Ma megióo centro

B) Y ustedes, ¿en cuáles situaciones utilizan el "tu", el "você" o el "senhor"? En sus opiniones, ¿Qué aspectos pueden influenciar los usos de una forma $u$ otra?

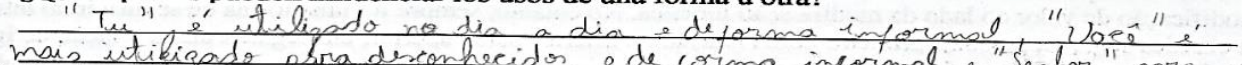

C) Y a la hora de traducir, ¿les parece adecuado utilizár la forma de tratamiento más corriente en la región del público meta de su traducción? ¿Por qué?

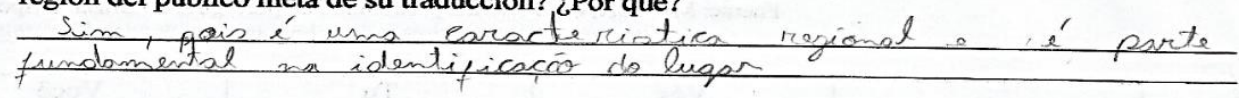
cont..

B) tratomanto formal ou passoas mais velhos.

Fonte: Grupo III, Pereira (2016).

Por sua vez, no item B, os grupos foram indagados sobre quais as formas de tratamento que eles próprios utilizavam e o que poderia influenciar a escolha dessas formas para eles. $\mathrm{O}$ G-I respondeu que usava pouco a forma "tu”, em comparação à forma "você", que era mais utilizada em contextos informais e de intimidade. Além disso, argumentou que usava a forma "senhor(a)" para se dirigir a pessoas com mais idade ou a autoridades em contexto formal. Por outro lado, o G-II e o G-III (Figura anterior) indicaram que a forma "tu" era utilizada por eles em contextos informais e de intimidade, enquanto a forma "você" era usada com pessoas com pouca intimidade ou desconhecidos, de uma maneira informal. Quanto à forma "senhor(a)", as respostas desses dois grupos coincidiram com as do G-I. Já o G-IV apontou que as formas "tu e você" eram usadas em contextos entre iguais e em situações informais. Sobre o que influenciava a escolha dessas formas, apenas este último grupo informou que essa escolha variava dependendo da região e da situação, dando o exemplo das relações professor-aluno e chefe-empregado, em que o uso da forma "senhor" indicava maior respeito com o interlocutor, conforme a figura a seguir.

Figura 12 - Respostas do G-IV à terceira questão do Módulo 8

\footnotetext{
A) En muchas regiones brasileñas el " $\mathrm{x} o c \hat{e}^{\text {" }}$ es de uso predominante para las situaciones de intimidad o informalidad. Entre los fragmentos de conversaciones presentados, en cuáles se presentó el pronombre " $\mathrm{x}$ lecê" $\mathrm{y}$ sus variantes como forma de tratamiento2 Además, ¿hay alternancias con el pronombre " $t u$ "?

En la frase del brasiliense y del paulista, pero en la habla del brasiliense hay uso también de tu.

B) Y ustedes, ¿en cuáles situaciones utilizan el "tu", el "xocê" o el "senhox"? En sus opiniones, ¿Qué aspectos pueden influenciar los usos de una forma $u$ otra?

Tu e xocê generalmente son utilizados en la informalidad o entre iguales, pero senhor se utiliza en situaciones de respecto o de una persona de poca edad para un mayor. La influencia depiende mucho de región y de situación, se quieres demonstrar respecto con profesores, en ul trabajo al hablar con el chefe o un cliente el brasileño prefiere usar el senhor-

C) $\mathrm{Y}$ a la hora de traducir, ¿les parece adecuado utilizar la forma de tratamiento más corriente en la rcgión del público meta de su traducción? ¿Por qué?

De acuerdo con las hablas paulistas estudiadas, se usan más las formas você e cê.
}

Fonte: Grupo IV, Pereira (2016).

PONTES; PEREIRA. A construção dos módulos de uma sequência didática a partir da tradução funcionalista para o ensino da variação linguística

Belas Infiéis, v. 7, n. 1, p. 175-200, 2018. 
Por fim, no item C, os grupos foram questionados sobre a atitude de considerar a forma de tratamento mais corrente na região do público-meta ao fazer uma tradução. Sobre esse item, todos os grupos reconheceram que era importante adequar a forma de tratamento ao receptor, por exemplo, o G-I e o G-II destacaram que essa atitude melhoraria a compreensão da tradução. O G-III justificou que essa atitude é fundamental na identificação do lugar da tradução, já que seria uma característica regional. Por seu turno, o G-IV apenas pontuou as formas de tratamento mais usuais na região do seu público-meta, que são os pronomes "você" e "cê" (Figura 12). Inferimos que essa questão influenciaria a atitude dos grupos ao traduzir a variação diatópica das formas de tratamento pronominais da Língua Espanhola, já que no módulo anterior estudaram um pouco da variação espanhola nas formas de tratamento e nesse módulo reconheceram a importância de adaptar a tradução dessas formas à região de seu receptor-meta.

\section{Considerações Finais}

A partir do exposto, constatamos que é possível uma aproximação teórica e prática entre o procedimento de SD, a Tradução Funcionalista e a Sociolinguística, uma vez que todas essas

196 perspectivas de estudo têm um ponto em comum: os gêneros textuais.

Por tratarmos, nesse artigo, especificamente, sobre a elaboração e aplicação dos módulos de uma SD com a tradução funcionalista do gênero textual peça de teatro hispânica ao português brasileiro, consideramos que a sequência de módulos propostos: i) teve como base as dificuldades dos participantes da SD no que se refere à análise pré-tradutória e à produção da primeira tradução; ii) buscou um equilíbrio na abordagem das capacidades de linguagem, apesar de dar prioridade às capacidades linguístico-discursivas, devido ao fenômeno de variação linguística contemplado, isto é, as formas de tratamento no Espanhol e no Português brasileiro; iii) pode ser classificada como uma sequência de progressão estável, conforme Mosquera Roa e Sánchez Abchi (2015), já que abordam temas do funcionamento linguístico em todos os módulos, visando melhorar a produção final.

Ainda, levando em conta a análise dos módulos apresentados, também, constatamos que eles cumpriram os seus objetivos, ao abordar, por exemplo, a planificação e a organização textual do gênero peça de teatro (comédia), além de explorar questões específicas da variação nas formas de tratamento pronominais no par linguístico envolvido. A reflexão sociolinguística pôde ser reforçada com a criação de módulos específicos para a análise dos condicionamentos linguísticos e extralinguísticos no uso destas formas linguísticas, nas duas línguas.

PONTES; PEREIRA. A construção dos módulos de uma sequência didática a partir da tradução funcionalista para o ensino da variação linguística

Belas Infiéis, v. 7, n. 1, p. 175-200, 2018. 
Em relação aos estudos realizados com a tradução funcional e o uso de SD, destacamos que nossa pesquisa contribuiu, no âmbito prático-didático do ensino e aprendizagem de Espanhol na era do pós-método, ao preencher uma lacuna no que diz respeito à aplicação de propostas didáticas acerca da Tradução e da Sociolinguística Educacional, no contexto de formação de professores de Espanhol no Brasil. Além disso, propusemos uma abordagem didática para o ensino das formas de tratamento pronominais do Espanhol e do Português Brasileiro (PB), considerando graus de simetria e assimetria entre os interlocutores, associada a condicionamentos sociais e estilísticos. Em nossa proposta, também, refletimos sobre a prática tradutória funcionalista no que tange ao par linguístico Espanhol-PB, fomentando a conscientização da influência do contexto situacional no ato tradutório (PONTES, 2014).

\section{REFERÊNCIAS BIBLIOGRÁFICAS}

BARRIENTOS, Brenda Rocio Ruesta. Os quadrinhos da Mateina no ensino de Espanhol língua estrangeira: à luz da Tradução Funcionalista. 2014. 252f. Dissertação (Mestrado em Estudos da Tradução) - Centro de Comunicação e Expressão. Universidade Federal de Santa Catarina: Florianópolis, 2014.

BARROS, Eliana Merlin Deganutti. Gestos de ensinar e de aprender gêneros textuais: a sequência didática como instrumento de mediação. 2012. 368 f. Tese (Doutorado em Estudos da Linguagem) - Centro de Letras e Ciências Humanas, Universidade Estadual de Londrina, Londrina, 2012.

O gênero textual como articulador entre o ensino da língua e a cultura midiática. In: NASCIMENTO, E. L. Gêneros textuais: da didática das línguas aos objetos de ensino. Campinas: Pontes Editores, 2014. p. 137-168

BOLAÑOS-CUÉLLAR, Sergio. Aproximación Sociolingüística a la Traducción. Forma y Función, no 13. P.157-192, 2000. Disponível em: 〈http://goo.gl/rXX1rz>. Acesso em: 20 mai. 2014.

COAN, Márluce; PONTES, Valdecy de Oliveira. Variedades linguísticas e ensino de Espanhol no Brasil. Revista Trama (UNIOESTE. Online), v. 09, 2013. p. 179-191.

COSTA-HÜRBES, Terezinha da Conceição; SIMIONI, C. A. Sequência didática: uma proposta metodológica curricular de trabalho com os gêneros discursivos/textuais. In: BARROS, E.M.D.; RIOS-REGISTRO, E.S. Experiências com sequências didáticas de gêneros textuais. Campinas: Pontes Editores, 2014.

CRISTOVÃO, Vera Lúcia Lopes. Sequências didáticas para o ensino de línguas. In: DIAS, R; CRISTOVÃO, V.L.L. O livro didático de língua estrangeira. Múltiplas perspectivas. Mercado de Letras: Campinas, SP, 2009. p. 305-344.

PONTES; PEREIRA. A construção dos módulos de uma sequência didática a partir da tradução funcionalista para o ensino da variação linguística 
O gênero quarta capa no ensino de inglês. In: DIONISIO, A. et. al. (Org.). Gêneros textuais e ensino. São Paulo: Parábola, 2010. p. 105 - 116.

DOLZ, Joaquim; NOVERRAZ, M; SCHENEUWLY, Bernard. Sequências didáticas para o oral e a escrita: apresentação de um procedimento. In: ROJO, R.; CORDEIRO, G.S. (Trad. e Org.) Gêneros orais e escritos na escola.Mercado de Letras: Campinas, 2004. p. 95-128.

FONTANELLA DE WEINBERG, Maria Beatriz. Sistemas pronominales de tratamiento usados en el mundo hispánico. In: Bosque, I. /Demonte, V. (eds.): Gramática Descriptiva de la lengua española, 1. Madrid: RAE, 1999. p. 1399-1425.

LABOV, William. Where does the Linguistic variable stop? A response to Beatriz Lavandera. Sociolinguistic Working Paper, 44, 1978.

MARCUSCHI, Luiz Antônio. Gêneros textuais: definição e funcionalidade. In: DIONISIO, A. et. al. (Org.). Gêneros textuais e ensino. São Paulo: Parábola, 2010. p. 19-38.

MENON, Odete Pereira da Silva. O sistema pronominal do Português do Brasil. Curitiba. Editora da UFPR, n 44, p. 91-106. 1995. 〈http://goo.gl/gWxl10〉 Acesso em: 10 mai. 2015.

MOSQUERA ROA, Santiago; SANCHEZ ABCHI, Verónica. Las secuencias didácticas de género textual en ELE. Perspectivas para una formación docente. In: GARCÍA-AZKOAGA,

198 I. M.; IDIAZABAL, I. (Eds.). Para una ingeniería didáctica de la educación plurilingüe. Bilbao: Universidad del País Vasco, Servicio Editorial, D.L, 2015.

NORD, Christiane. Traduciendo funciones. In: HURTADO ALBIR, A. (ed.): Estudios sobre la traducción. Castelló: Publicacions de la Universitat Jaume I, 1994. p. 97-112.

El error en la traducción: categorías y evaluación. In: HURTADO ALBIR, A.

Estudios sobre la traducción. Castelló: Universitat Jaume I, 1996. p. 91-107. Disponível em: <http://goo.gl/SdW35b >. Acesso em: 20 fev. 2015.

Texto-base-texto-meta. Un modelo funcional de análisispretraslativo. Tradução e adaptação de Christiane Nord. Castelló de la Plana: Publicacions de la Universitat Jaume I, Espanha, 2012.

PAIVA; M.C.A.; DUARTE, M.E.L. Quarenta anos depois: a herança de um programa na Sociolinguística Brasileira. In: WEINREICH, U.; LABOV, W.; HERZOG, M. Tradução de Marcos Bagno. Fundamentos empíricos para uma teoria da Mudança Linguística. São Paulo: Parábola, 2006. [1968] p. 131- 151.

PEREIRA, Livya Lea de Oliveira. A tradução de textos teatrais como recurso didático para o ensino da variação linguística no uso das formas de tratamento em espanhol a aprendizes brasileiros. 315p. Dissertação (mestrado) - Universidade Federal do Ceará, Centro de Humanidades, Programa de Pós-Graduação em Estudos da Tradução, Fortaleza, 2016. 
PONTES, Valdecy de Oliveira. A tradução da variação linguística e o ensino de língua estrangeira: da teoria à prática docente. Caderno de Letras da UFF - Dossiê: Tradução, $\mathbf{N}^{\circ}$ 48, p.223-237, Nov. 2014.

REISS, Katherina; VERMEER, Hans J. Fundamentos para una teoría funcional de la traducción. Tradução de Sandra García Reina e Celia Martín de León. Madrid: Ediciones Akal, 1996. 206p.

ROMÃO, Tito Lívio Cruz. Definições de Tradução e Evolução dos Estudos Tradutórios. In: MATTES, M; THEOBALD, P. Ensino e Cultura Contemporânea. Fortaleza: Edições UFC, 2010. p. 31-46.

SCHERRE, Maria Marta Pereira, et. al. Variação dos pronomes Tu e você. In: MARTINS, M.A; ABRAÇADO, J. (org.) Mapeamento sociolinguístico do Português Brasileiro. São Paulo: Contexto, 2015. p.133-172.

WEINREICH, U.; LABOV, W.; HERZOG, M. Tradução de Marcos Bagno. Fundamentos empíricos para uma teoria da Mudança Linguística. São Paulo: Parábola, 2006. [1968] ZIPSER, Meta Elizabeth; POLCHLOPEK, Silvana Ayub. Introdução aos Estudos da Tradução. Curso de Licenciatura de Letras Espanhol na Modalidade a Distância. Florianópolis: UFSC, 2011.

\footnotetext{
1 Valdecy de Oliveira Pontes - Professor do Departamento de Letras Estrangeiras e dos Programas de Pósgraduação em Linguística (PPGL) e Estudos da Tradução (POET) da Universidade Federal do Ceará (UFC). Pósdoutor em Estudos da Tradução (2014) pela Universidade Federal de Santa Catarina (UFSC), Doutor (2012) em Linguística pela Universidade Federal do Ceará (UFC) e mestre em Linguística Aplicada (2009) pela Universidade Estadual do Ceará (UECE). Graduado em Letras - Português e Espanhol (2006) pela Universidade Federal do Ceará (UFC). Fortaleza, Ceará, Brasil. Lattes: http://lattes.cnpq.br/0958944549142686 ; Email:valdecy.pontes@ufc.br
}

${ }^{2}$ Livya Lea de Oliveira Pereira - Doutoranda em Linguística no Programa de Pós-Graduação em Linguística da Universidade Federal de Santa Catarina (PPGL/UFSC). Mestre em Estudos da Tradução (2016) pelo Programa de Pós-Graduação em Estudos da Tradução na Universidade Federal do Ceará (POET/UFC). Graduada em LetrasEspanhol (2014) pela mesma universidade. Florianópolis, Santa Catarina, Brasil. Lattes: http://lattes.cnpq.br/6540023967579544 ; E-mail: livyaoliveira010@gmail.com

${ }^{3}$ A competência comunicativa, primeiramente, foi definida por D. Hymes (1971), no âmbito da Sociolinguística e da Etnografia da Comunicação, em contraposição ao conceito de competência linguística dos gerativistas. Para este autor, a competência comunicativa trata-se da capacidade de produzir enunciados corretos gramaticalmente $\mathrm{e}$ adequados ao contexto social de fala. Com os avanços de estudos na área de metodologia e ensino de Línguas Estrangeiras, M. Canale (1983) retoma esta definição de competência comunicativa como a integração de quatro competências inter-relacionadas, a saber: a competência linguística, a competência sociolinguística, a competência discursiva e a competência estratégica.

\footnotetext{
${ }^{4}$ No âmbito da Sociolinguística, a língua possui função social e comunicativa e é fator importante na identificação de grupos e na demarcação de diferenças sociais na comunidade. Logo, a língua é dotada de "heterogeneidade sistemática" (WEINREICH; LABOV; HERZOG, [1968] 2006), em que o contexto social de uso envolve aspectos linguísticos e extralinguísticos, ocasionando fenômenos de variação linguística e mudança inerentes às línguas.

${ }^{5}$ Conforme Labov (1978), a variação linguística ocorre quando há duas ou mais alternativas de se referir ao mesmo estado de coisas com o mesmo valor referencial.
}

PONTES; PEREIRA. A construção dos módulos de uma sequência didática a partir da tradução funcionalista para o ensino da variação linguística

Belas Infiéis, v. 7, n. 1, p. 175-200, 2018. 


\begin{abstract}
${ }^{6}$ Nesta pesquisa, ao utilizar os termos "nível inicial", estaremos nos referindo ao nível de aprendizagem A1/A2, igualmente, os termos "nível intermediário" e "nível avançado" se referem, respectivamente, aos níveis B1/B2 e C1/C2 do Quadro Europeu Comum de Referência para as Línguas. Este documento guia a elaboração e produção de material didático para aprendizagem de língua em todo o continente europeu, além de descrever o que os aprendizes devem saber comunicar em cada nível de aprendizagem. É um documento relevante, pois a maioria dos livros didáticos de Espanhol como Língua Estrangeira que circula no mercado brasileiro é proveniente da Espanha, conforme Pontes e Coan (2013).

${ }^{7}$ Fontanella de Weinberg (1999) propõe a divisão dos sistemas de tratamento pronominais da Língua Espanhola, a partir de quatro sistemas, no qual o Sistema III é subdividido em III.a e III.b. Baseando-nos nesta divisão, apresentada na seção 3.2.1, selecionamos 5 países para a escolha das peças teatrais, um para cada sistema proposto por esta divisão, a saber: Espanha (Sistema Pronominal I); Porto Rico (Sistema Pronominal II); Uruguai (Sistema Pronominal III.a); Chile (Sistema Pronominal III.b) e Argentina (Sistema Pronominal IV)
\end{abstract}

${ }^{8}$ Disponível em: <https://www.youtube.com/watch?v=HwHfkuRCflc〉. Acesso em: 10 mar.17. 